Proc. Indian Acad. Sci. (Earth Planet. Sci.), Vol. 99, No. 1, March 1990, pp. 57-80.

(C) Printed in India.

\title{
A review and assessment of experiments on Kimberlites, Lamproites and Lamprophyres as a guide to their Origin
}

\author{
STEPHEN F FOLEY, \\ Max-Planck-Institut für Chemie, Abt. Kosmochemie Saarstrasse 23, $6500 \mathrm{Mainz}$, West \\ Germany
}

\begin{abstract}
Liquidus experimental studies on kimberlite, lamproite and lamprophyre compositions are reviewed with respect to the information they carry on the mantle origin of these rock types. This information is coupled with melting experiments on peridotite in the presence of $\mathrm{H}_{2} \mathrm{O}$ and mixed $\mathrm{H}_{2} \mathrm{O}+\mathrm{CO}_{2}$ volatile species.

The origin of most lamproites is explained by the melting of mica-harzburgite assemblages at depths ranging from $40 \mathrm{~km}$ for leucite lamproites to more than $150 \mathrm{~km}$ for olivine lamproites. Clinopyroxene-rich, silica-poor lamproites remain enigmatic, but are possibly derived by the melting of a mica-bearing ultramafic source richer in clinopyroxene and under more oxidized, $\mathrm{CO}_{2}$-bearing conditions. There are insufficient experimental studies on kimberlite to reasonably constrain their origin, and what remain are only general indications of the compositions of partial melts of mantle under volatile-bearing conditions. Melt compositions are not sufficiently well known to prevent very conceptual use of melt 'names' such as 'kimberlitic' or 'carbonatitic', and melts similar to alkaline and ultramafic lamprophyre may be hidden under this shroud.

Clearer definition of the origins of alkaline melt compositions such as kimberlites and various lamprophyre types badly reeds more exact bracketing of melt compositions of a variety of possible mantle mineral assemblages. The recently-developed sandwich reversal technique is ideally suited to study small degrees of partial melting, and could usefully be applied to lherzolitic and non-lherzolitic materials with hydrous and/or carbonate minerals.
\end{abstract}

Keywords. Kimberlites; lamproites; lamprophyres; liquidus experiments; volcanic rocks; alkaline lamprophyres; ultramafic lamprophyres; peridotite partial melting; lherzolitic systems.

\section{Scope}

The purpose of this contribution is to summarize experimental work of the past twenty years which has improved our understanding of the conditions of origin of kimberlites, lamproites and lamprophyres. The experimental studies discussed here include work on simple systems, single mineral stabilities, and natural rock compositions or their synthetic analogues. I shall use the subdivision into 'forward' and 'reverse' directions outlined by Wyllie et al (1981) which emphasizes the complementary nature of liquidus and partial melting studies, and forms a useful basis for integration of experimental results with other petrological and geochemical studies.

The reverse approach starts with the rocks as we see them at the Earth's surface, and attempts to infer conditions of origin of the magmas. In experimental terms, this means liquidus studies of rock compositions which aim to discover multiple phase saturation at the liquidus, particularly as a function of pressure, temperature, and volatile contents. The point at which any such multiple saturation occurs may indicate the conditions of origin of the melt, and the mineralogy of the source rock. 
The forward approach consists of modelling mantle source compositions from a variety of lines of evidence, and conducting partial melting experiments on these compositions in order to determine compositions of their partial melting products at various temperatures and pressures.

A recurring aspect in this review is the approximative nature of experimental petrology. The forward and reverse approaches are complementary, tackling a problem from different directions but still requiring interpolation to meet in the middle. Simple systems, used mostly in the forward approach, have the advantage of being theoretically analysable, but require extrapolation to more complex natural compositions. Where experiments on the natural compositions later become available as in peridotite melting experiments, the approximations of extrapolation from simple systems become exposed. The reader of experimental reports must beware of overoptimistic interpretations; although the limitations are often stated in the original reports, they tend to become brushed aside in later quotations.

This review does not aim to be an exhaustive survey of peridotite melting experiments, but will be pragmatically selective, picking out the studies on the effect of volatiles on partial melting, since these are considered essential to the generation of basic/ultrabasic alkaline melts. Recently developed techniques are outlined which enable better definition of low-degree melt compositions which are important for studies of carbonatites and ultramafic lamprophyres.

\section{Liquidus experiments on kimberlites, lamproites and lamprophyres}

\subsection{Aims and principles of liquidus studies of volcanic rocks}

Liquidus experimental studies of volcanic rocks fall into two main categories - those aimed at identifying crystal fractionation sequences, and those aimed at identifying the mineralogy of the source rocks. This paper concentrates on the second type of study.

An important starting point for liquidus multiphase saturation studies is the identification of a primary magma, for which the most primitive magma in a volcanic region is often used. The principle used is that a primary magma, namely, a magma whose composition is unchanged since it left the source region in equilibrium with the minerals in the source, will have a unique point on its liquidus at which multiple saturation occurs in these source minerals, and this point should indicate the pressure and temperature of origin. The minerals that appear at this liquidus point should additionally have the same compositions as those in the source. Furthermore, other parameters which affect phase relationships such as volatile components and oxygen fugacity must also be correctly applied in experiments in order to find the point of multiple saturation. Accessory minerals which were present in the source when melting began, but were eliminated from the solid fraction before the melt separated (i.e. those that are present to lower degrees of partial melting than represented by the melt) should not appear at the liquidus, but should be seen at subliquidus temperatures.

However, the existence of rocks which represent primary magmas at the Earth's surface is doubtful and although estimated compositions are sometimes used after consideration of likely fractionation effects from petrological and geochemical studies, it is not likely that compositions subjected to liquidus studies do represent primary 
magmas. One must therefore expect not to find a point of multiple saturation, but to have to account for differences between the phase relationships seen and the likely source. Given these stringent requirements both in terms of starting composition and in experimental conditions applied, it is astonishing how often claims to have found such multiple saturation points are made. Therefore, the discovery of multiple saturation points should, wherever possible, be backed by evidence from partial melting studies of the suspected source materials. As emphasized by Wyllie et al (1981), liquidus studies are probably more useful where they give negative results, i.e. when studies show that under certain conditions a melt could not have been produced.

\subsection{Kimberlites}

Despite decades of interest in the origin of kimberlites, there are only two liquidus surveys of kimberlite compositions at high pressure. These are the studies of Eggler and Wendlandt $(1978,1979)$ on an average Lesotho kimberlite composition, and the recent study of Edgar et al (1988) on a lower silica Wesselton kimberlite. The main reasons for this dearth of experimental work are twofold, (i) the uncertainty about the compositions of kimberlite primary melts, if they exist at all, and (ii) the scarcity of experimental facilities capable of investigating pressures and temperatures relevant to kimberlite genesis $\left(40-60 \mathrm{~kb}, 1200-1600^{\circ} \mathrm{C}\right)$ with sealed capsules containing fluids.

Kimberlites are mantle-derived, and modification of the composition by lowpressure fractional crystallization, which dominates the geochemical behaviour of most common basalt types, appears to be extremely limited (see reviews by Dawson 1980; Mitchell 1986). The problem in defining a kimberlite primary magma is caused instead by the amount of 'foreign' material found in kimberlites, namely ultramafic xenoliths and disaggregated pieces there of, megacrysts, and crustal xenoliths. The crustal xenoliths, together with groundwater alteration of the kimberlite, are believed to cause an increase in silica content. Another feature causing problems for simple models of kimberlite origin by partial melting of peridotite is the high $\mathrm{CaO}$ content which correlates with $\mathrm{CO}_{2}$ content, leading to suggestions of 'contamination' of kimberlite by $\mathrm{CO}_{2}$-rich fluid (e.g. Brey 1978; Bailey 1984). Although the problem of increase in silica by near-surface contamination is better understood following the comparison of diatreme and dyke facies kimberlites, the composition of kimberlite primary magmas is still a matter of debate.

The starting compositions used in the liquidus experiments are listed in table 1 (analyses 1 and 2). The problem of alteration has been partly tackled, but by different means, in the two studies. Eggler and Wendlandt (1978) chose to study an average Lesotho kimberlite composition assuming all $\mathrm{CO}_{2}$ to be mantle-derived, but omitting all $\mathrm{H}_{2} \mathrm{O}$ from the synthetic starting material on the assumption that all $\mathrm{H}_{2} \mathrm{O}$ was of meteoric origin. Known amounts of water were then added to the charge before each run. $\mathrm{CoO}$ was used as a proxy for $\mathrm{FeO}$ to avoid alloying problems with $\mathrm{Pt}$ capsules; $\mathrm{CoO}$ has the effect of raising liquidus temperatures by approximately $50^{\circ} \mathrm{C}$ (Eggler and Wendlandt 1978). The Wesselton kimberlite studied by Edgar et al (1988) is a lower-silica, calcite-rich, aphanitic kimberlite, chosen to avoid inclusion of megacryst and xenolithic material, and in which calcite and $\mathrm{H}_{2} \mathrm{O}$ are assumed to be a part of the mantle-derived composition. The two compositions differ mostly in their $\mathrm{SiO}_{2}, \mathrm{CaO}$ and volatile contents. 
Table 1. Starting compositions (wt $\%$ ) used in high pressure liquidus experiments on kimberlite, lamproite and alkaline lamprophyre compositions.

$\mathrm{Mg} \mathrm{No} .=100 \mathrm{Mg} /(\mathrm{Mg}+\mathrm{Fe})$ calculated on a molar basis with all $\mathrm{Fe}$ as $\mathrm{FeO}$

ROCK = natural rock; SYN = synthetic starting mixture - sintered oxide or glass

\begin{tabular}{|c|c|c|c|c|c|c|c|c|c|}
\hline & 1 & 2 & 3 & 4 & 5 & 6 & 7 & 8 & 9 \\
\hline $\mathrm{SiO}_{2}$ & 25.6 & 37.68 & $55 \cdot 14$ & $50 \cdot 2$ & $43 \cdot 56$ & 44.65 & $51 \cdot 37$ & $43 \cdot 78$ & $49 \cdot 13$ \\
\hline $\mathrm{TiO}_{2}$ & 3.35 & $2 \cdot 16$ & 2.58 & $2 \cdot 30$ & $2 \cdot 31$ & 6.92 & 3.45 & 3.86 & 2.02 \\
\hline $\mathrm{Al}_{2} \hat{\mathrm{O}}_{3}$ & $3 \cdot 31$ & $5 \cdot 11$ & $10 \cdot 35$ & $11 \cdot 39$ & 7.85 & $2 \cdot 75$ & 9.95 & 4.49 & $10-51$ \\
\hline $\mathrm{Fe}_{2} \mathrm{O}_{3}$ & $10 \cdot 30$ & - & 3.27 & 0.57 & 5.57 & 6.94 & - & - & 3.82 \\
\hline $\mathrm{FeO}$ & - & - & 0.62 & $4 \cdot 23$ & 0.85 & $1 \cdot 36$ & 6.05 & $8 \cdot 67$ & $4 \cdot 30$ \\
\hline $\mathrm{CoO}$ & - & $11 \cdot 27$ & - & - & - & - & - & - & - \\
\hline $\mathrm{MgO}$ & $27 \cdot 2$ & $25 \cdot 85$ & 6.41 & $7 \cdot 23$ & $11-03$ & $14 \cdot 39$ & 8.03 & 23.79 & 9.87 \\
\hline $\mathrm{CaO}$ & $15 \cdot 30$ & $10 \cdot 62$ & 3.45 & 600 & 11.89 & 3.81 & 4.67 & 5.08 & 9.06 \\
\hline $\mathrm{Na}_{2} \mathrm{O}$ & 0.28 & 0.22 & 1.21 & 0.86 & 0.74 & 0.83 & 1.67 & 0.58 & 2.06 \\
\hline $\mathrm{K}_{2} \mathrm{O}$ & 0.70 & 0.91 & $11 \cdot 77$ & $10 \cdot 19$ & $7 \cdot 19$ & 6.80 & 11.76 & 5.08 & 4.86 \\
\hline $\mathrm{P}_{2} \mathrm{O}_{5}$ & 1.83 & 0.74 & 1.40 & 1.89 & 1.50 & $1 \cdot 41$ & 1.50 & 1.64 & 0.97 \\
\hline $\mathrm{Cr}_{2} \mathrm{O}_{3}$ & 0.352 & 0.23 & 0.04 & - & 0.04 & 0.049 & $0 \cdot 10$ & 0.17 & - \\
\hline $\mathrm{NiO}$ & 0.103 & - & - & - & - & 0.032 & 0.03 & 0.13 & - \\
\hline $\mathrm{BaO}$ & $0 \cdot 112$ & - & 0.52 & - & $0-66$ & $2 \cdot 62$ & 0.63 & 1.75 & - \\
\hline $\mathrm{SrO}$ & $0 \cdot 14$ & - & 0.26 & - & $0-40$ & 0.214 & 0.23 & $0 \cdot 15$ & - \\
\hline $\mathrm{ZrO}_{2}$ & 0.078 & - & 0.27 & - & 0.27 & 0.266 & $0 \cdot 14$ & 0.15 & - \\
\hline $\mathrm{MnO}$ & 0.21 & - & $0-06$ & 0.07 & 0.15 & 0.078 & 0.09 & $0 \cdot 17$ & 0.12 \\
\hline $\mathrm{H}_{2} \mathrm{O}^{+}$ & $6 \cdot 20$ & - & $1 \cdot 23$ & 3.59 & $2 \cdot 89$ & 3.22 & - & - & $2 \cdot 36$ \\
\hline $\mathrm{CO}_{2}$ & $4 \cdot 77$ & $5 \cdot 22$ & - & - & - & 0.93 & - & - & - \\
\hline $\mathbf{F}$ & $0 \cdot 25$ & - & - & - & - & 0.59 & 0.33 & 0.53 & - \\
\hline Sum & $100 \cdot 08$ & $100 \cdot 01$ & $98 \cdot 58$ & 98.52 & 96.90 & 97.86 & $100 \cdot 00$ & $100 \cdot 02$ & $99 \cdot 08$ \\
\hline Mg No. & $84 \cdot 0$ & $80.9^{*}$ & $76 \cdot 2$ & $73 \cdot 1$ & $77 \cdot 0$ & $77 \cdot 1$ & $70-3$ & $83 \cdot 0$ & $69 \cdot 4$ \\
\hline Mix & ROCK & SYN & ROCK & ROCK & ROCK & ROCK & SYN & SYN & ROCK \\
\hline
\end{tabular}

$1=$ Wesselton kimberlite (Edgar et al 1988), 2 = average Lesotho kimberlite (Eggler and Wendlandt 1978, 1979). Sources for other compositions (3-9) given in table 2.

* = $\mathrm{Mg}$ No. calculated for original $\mathrm{FeO}$ content (all $\mathrm{Fe}$ as $\mathrm{FeO}$ )

The results of both studies are shown in pressure-temperature plots in figure 1 , which are from experiments with comparable volatile composition of $\mathrm{CO}_{2} / \mathrm{H}_{2} \mathrm{O}$ about 1. The Lesotho kimberlite has olivine, orthopyroxene and clinopyroxene near the liquidus at both pressures studied $(30$ and $55 \mathrm{~kb}$ ), and extrapolation of the garnetin curve shows that all four lherzolite phases will be within $100^{\circ} \mathrm{C}$ of the liquidus at $60 \mathrm{~kb}$. Eggler and Wendlandt (1979) took this to indicate that kimberlite could be a partial melting product of lherzolite at about this pressure, noting that it is remarkable that an average kimberlite composition shows these liquidus relationships. It is interesting to note that in the melting of phlogopite-carbonatelherzolite (see $\S 3$ ) that magnesite and phlogopite occur only more than $300^{\circ} \mathrm{C}$ below the liquidus at $55 \mathrm{~kb}$. These curves are estimated in figure $1 \mathrm{~b}$, but are constrained to lie at such low temperatures by experiments with lower $\mathrm{CO}_{2} / \mathrm{H}_{2} \mathrm{O}$ (Eggler and Wendlandt 1979). The principles discussed above indicate that if kimberlite is a partial melting product of phlogopite-carbonate-lherzolite at about $60 \mathrm{~kb}$, then magnesite and phlogopite were not residual phases, but were eliminated at considerably lower melt fractions than represented by the kimberlite.

The Wesselton kimberlite could unfortunately be studied only up to $40 \mathrm{~kb}$, but the results are interesting due to the presence of calcite at $30 \mathrm{~kb}$ and the absence of 


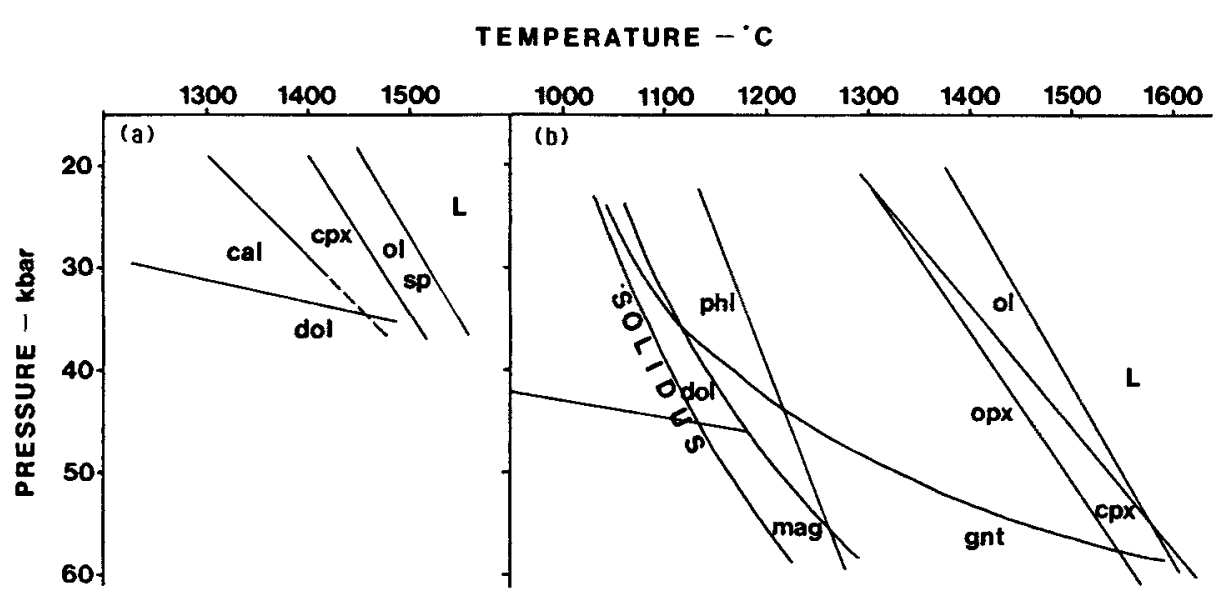

Figure 1. Liquidus diagram for (a) Wesselton kimberlite-(after Edgar et al 1988) and (b) average Lesotho kimberlite (after Eggler and Wendlandt 1978, 1979). These diagrams are for $\mathrm{CO}_{2} / \mathrm{H}_{2} \mathrm{O}$ of approximately 1 : see original publications for other volatile contents. Mineral names are given immediately to the low temperature side of their first appearance, but they remain stable at lower temperatures. Mineral abbreviations for figures 1-7: cal = calcite; $\quad$ dol $=$ dolomite; $\quad \mathrm{cpx}=$ clinopyroxene; $\quad$ opx $=$ orthopyroxene; $\quad \mathrm{ol}=$ olivine; sp = spinel; $\quad$ mag = magnesite; gnt = garnet; lc = leucite; san = sanidine; ap = apatite; ks = kalsilite; $\mathrm{phl}=$ phlogopite; rut = rutile; ilm = ilmenite; $q \mathrm{z}=$ quartz; en = enstatite; fo $=$ forsterite.

orthopyroxene. Edgar et al (1.988) conclude that the results eliminate the possibility of the Wesselton kimberlite being a partial melt of lherzolitic mantle, but that it may originate in an orthopyroxene-free source region. If the source contains no orthopyroxene, then calcite is a possible mineral in the source, since the reactions which limit the possible carbonate minerals in lherzolites to magnesite and dolomite all involve orthopyroxene (Brey et al 1983). Dolomite occurs at $35 \mathrm{~kb}$ (figure 1a), but not in experiments with lower $\mathrm{CO}_{2} / \mathrm{H}_{2} \mathrm{O}$ (Edgar et al 1988).

\subsection{Lamproites}

Six lamproites have been studied experimentally at high pressures, and their compositions are listed in table 1 (analyses 3-8). A number of these studies date from before 1979 when the discovery of richly diamondiferous olivine lamproites in Western Australia (Atkinson et al 1984) sparked interest in the olivine-rich members of the lamproite suite. Consequently, only one of the compositions listed is an olivine lamproite (analysis 8), although a second study, on the Prairie Creek, Arkansas, olivine lamproite by E Walker of the University of Western Ontario, is in progress.

Table 2 lists experimental conditions for the lamproite studies (compositions A-F), and also for experiments on other ultrapotassic rocks $(\mathrm{G}-\mathrm{L})$. These other studies are considered since they broaden the base of experimental data on alkaline rocks, and provide additional information on the behaviour of $\mathrm{SiO}_{2}$-poor and $\mathrm{CO}_{2}$-rich compositions.

Primitive, if not primary, magmas have been assumed to be relatively common among the lamproites. The compositions discussed here were all said by their investigators to be near-primary, although in some cases the only criterion used to 


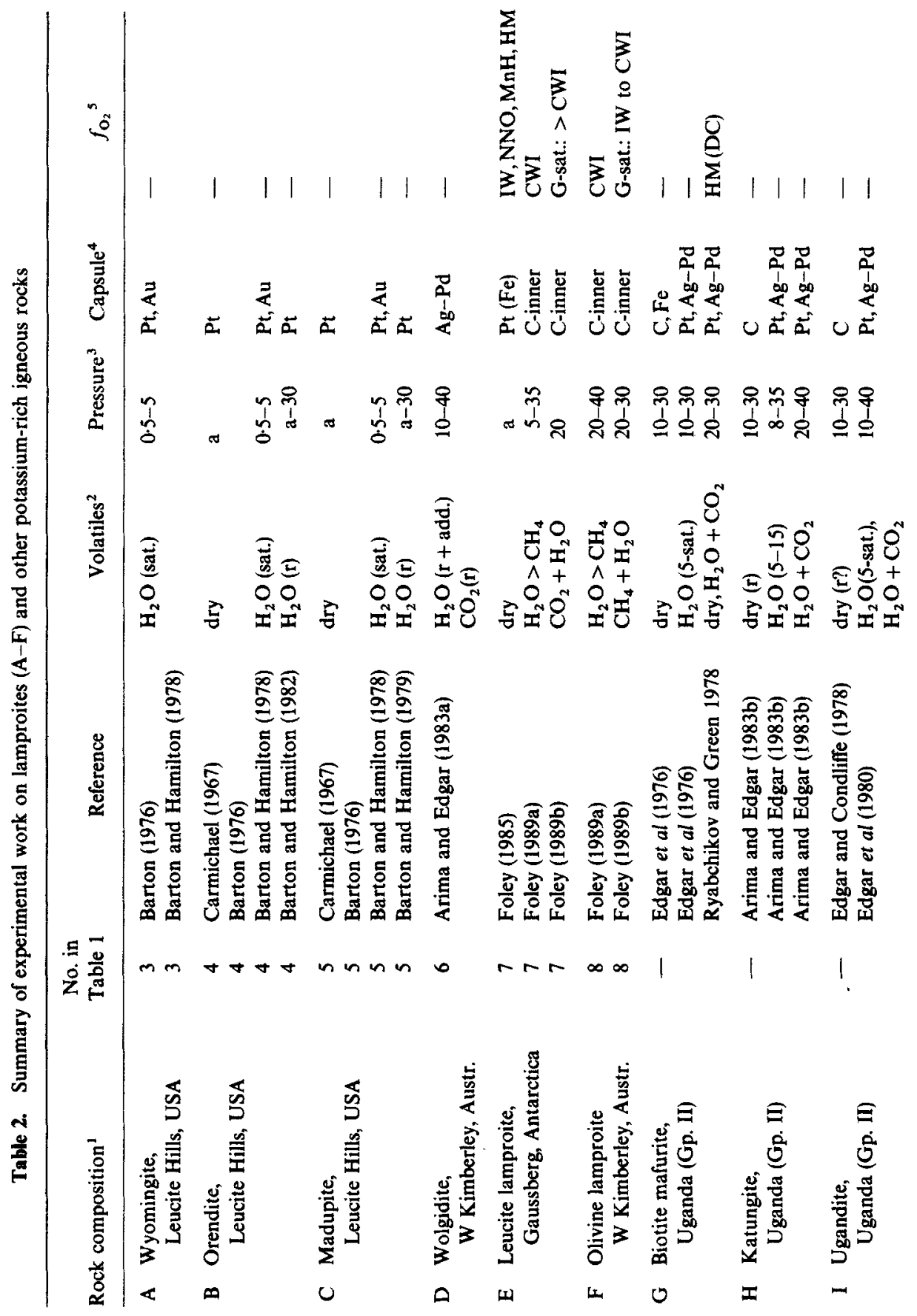




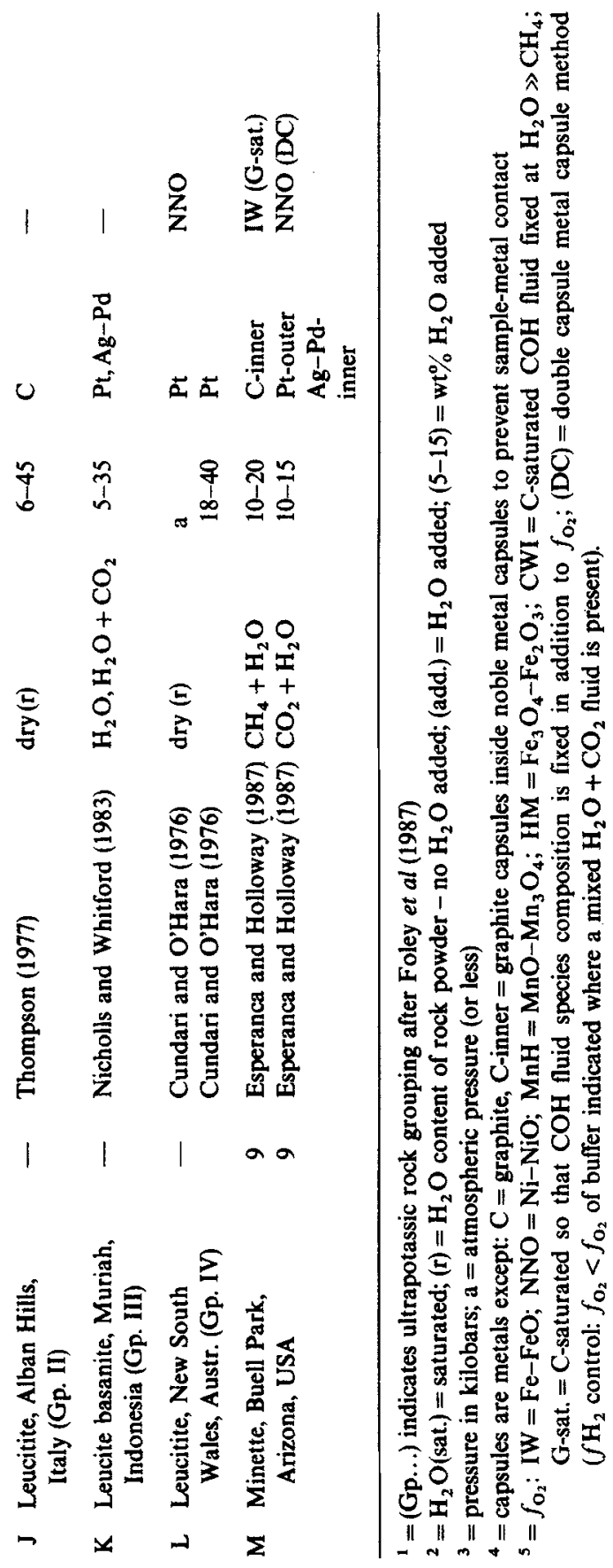


determine this was that the $\mathrm{Mg}$. No. be 70 or above. This value is taken directly from experiments on equilibrium between lherzolite and basalt, without allowance for the effects of compositional differences between basalts and lamproites. However, extensive studies of geochemistry within a lamproite volcanic field (Jaques et al 1984, 1986) have led to conclusions that a range of primary magmas exist, and that many non-primary magmas are still highly magnesian due to the depleted nature of the source in terms of major elements. Primary magmas of broadly olivine lamproitic composition certainly exist, and primary melts as silica-rich as $51 \mathrm{wt} \% \mathrm{SiO}_{2}$ are very likely, as indicated by the very glassy, spinel-lherzolite nodule-bearing olivine leucitite at Gaussberg (Sheraton and Cundari 1980). In addition to this range of melts are the 'madupitic' compositions with low $\mathrm{SiO}_{2}$ and much higher $\mathrm{CaO}$ than most lamproites (table 1, composition 5). In West Greenland, madupitic lamproites contain much larger amounts of $\mathrm{CO}_{2}$ (Scott 1979) than most lamproites which may indicate derivation from a distinct type of primary melt. In most lamproites, the important volatiles are $\mathrm{H}_{2} \mathrm{O}$ and $\mathrm{HF}$, with $\mathrm{CO}_{2}$ playing a relatively minor role (Bergman 1987, p. 167; Foley et al 1987, p. 119).

The experimental studies of the three lavas of Leucite Hills (A-C in table 2) were carried out before the development of techniques to include $\mathrm{CO}_{2}$ in experiments, and before the extent of Fe-loss to Pt capsules was documented (Stern and Wyllie 1975). The loss of $\mathrm{Fe}$ increases the temperature of the liquidus by about $30^{\circ} \mathrm{C}$ but is not thought to greatly affect the stability of the phases present. $\mathrm{CO}_{2}$ is apparently not an important factor in the genesis of leucite lamproites, and possibly also not for madupites. Since dried, ground rock powders were used in all the studies of Barton and Hamilton $(1978,1979,1982)$, some $\mathrm{CO}_{2}$ is included, but unfortunately no $\mathrm{CO}_{2}$ analysis is given for the madupite. A value of $0.48 \mathrm{wt} \% \mathrm{CO}_{2}$ is given for fresh madupite from the same locality by Kuehner et al (1981), and the experiments on madupite presumably contain a similar amount since the rock used was also fresh (Barton and Hamilton 1979). Uncertainty remains, however, since some altered madupites contain close to $3 \mathrm{wt} \% \mathrm{CO}_{2}$ (Kuehner et al 1981).

Barton and Hamilton (1978) studied the three lavas of Leucite Hills under watersaturated conditions to $5 \mathrm{~kb}$, expressly to determine crystal fractionation sequences in lamproitic lavas. Two of these compositions, the orendite as a representative of the two leucite lamproites, and the madupite as a possibly distinct magma type, were then studied at high pressures with no added volatiles. The latter two studies are of particular interest to us here. The liquidus diagram produced for madupite (Barton and Hamilton 1979) is depicted in figure 2 . Olivine is the liquidus phase at $5 \mathrm{~kb}$, but sinks progressively further below the liquidus towards higher pressures. At 25 to $>30 \mathrm{~kb}$, clinopyroxene is the liquidus phase followed by olivine and garnet at $60-70^{\circ} \mathrm{C}$ below the liquidus. No orthopyroxene crystallized under any of these conditions. Phlogopite appears approximately $50^{\circ} \mathrm{C}$ below the liquidus at pressures up to $20 \mathrm{~kb}$, above which it drops away to lower temperatures. Barton and Hamilton (1979) concluded that madupite could not be derived from lherzolite under hydrous conditions, and probably also not with mixed $\mathrm{H}_{2} \mathrm{O}+\mathrm{CO}_{2}$ volatiles, since although $\mathrm{CO}_{2}$ expands the phase volume of orthopyroxene, it also causes the olivine phase volume to shrink. They suggested that if madupite is close to being a primary magma, it could have been derived by partial melting of olivine-mica-clinopyroxenite, but that the mica was probably eliminated from the source during melting, thus explaining its absence at the liquidus in figure 2. For the latter conclusion, they drew 


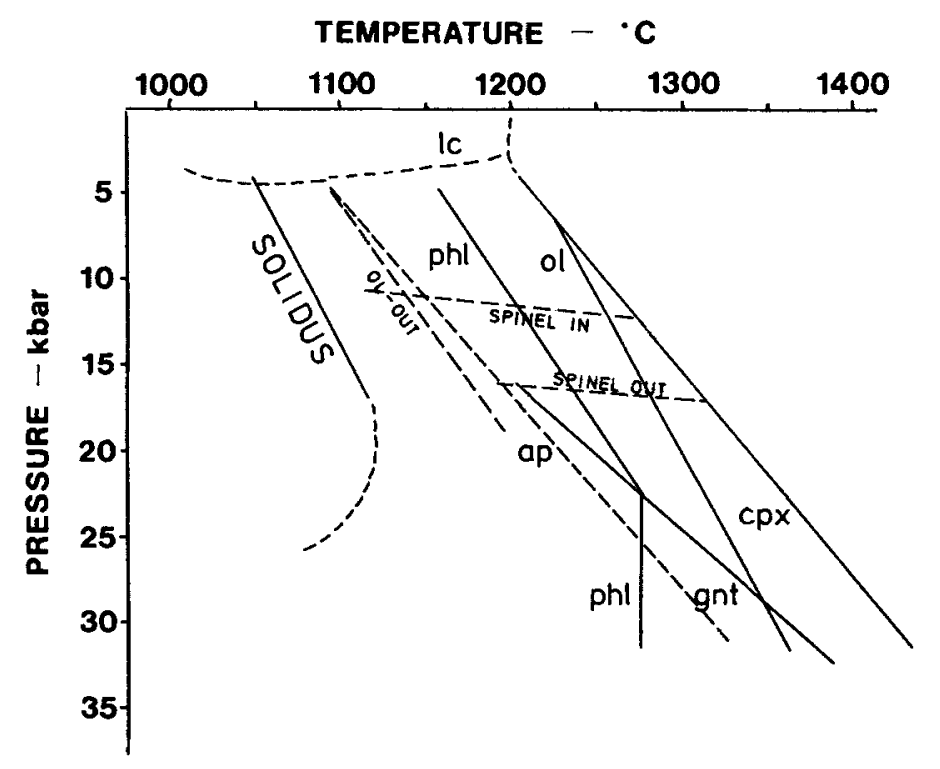

Figure 2. Liquidus diagram for madupite with no added volatiles (water-undersaturated with $2.9 \mathrm{wt} \% \mathrm{H}_{2} \mathrm{O}$ : after Barton and Hamilton 1979). Mineral names are shown to the low temperature side of their first appearance, and are stable to lower temperatures unless indicated by an 'out' curve (e.g. Ol-out). The leucite stability limit is estimated after Barton and Hamilton (1978). See figure 1 for abbreviations.

analogy from the study of biotite mafurite by Edgar, et al (1976, table 2 composition G), which showed that $15 \mathrm{wt} \% \mathrm{H}_{2} \mathrm{O}$ is required to stabilize phlogopite to liquidus temperatures. This they considered to be an unrealistically large amount.

The orendite composition studied at high pressures by Barton and Hamilton (1982) has an extreme $\mathrm{K}_{2} \mathrm{O}$ content of $11.8 \mathrm{wt} \%$ and is quartz-normative, with $\mathrm{SiO}_{2}$ content of $55 \mathrm{wt} \%$, and yet has a $\mathrm{Mg}$ No. of 76. It is thus an extremely silica-rich composition to be suspected of being of primary mantle origin. The water-undersaturated phase relationships, depicted in figure 3a, were interpreted by Barton and Hamilton (1982) to show a four-phase multiple saturation point with garnet, clinopyroxene, orthopyroxene and olivine at the liquidus at about $27 \mathrm{~kb}$. However, they considered the derivation of quartz-normative orendites from garnet lherzolite to be incompatible with indications from basaltic rock studies which show melts to be quartz-normative only below about $15 \mathrm{~kb}$, and suggested that only olivine orendites with approximately $10 \%$ normative olivine could be generated by partial melting of garnet lherzolite at $27 \mathrm{~kb}$.

The other two leucite lamproites listed in table 1 (compositions 6 and 7) have rather different compositions. The wolgidite was chosen as a 'primitive' magma because of its high Mg No. and Ni content (Arima and Edgar 1983a), whereas the Gaussberg lavas are very glassy and carry spinel lherzolite xenoliths despite lower $\mathbf{M g}$. No. Compositions 7 and 8 (table 1) were chosen as silica-rich and silica-poor members of a range of primary melts hypothesized to be derived from melting of mica harzburgite (Foley et al 1986a). Although the leucite lamproite is from Gaussberg, its composition is similar to that of West Kimberley leucite lamproites which may be primitive, and the presence of the xenoliths was taken to be a better indication of a little-altered, mantle- 


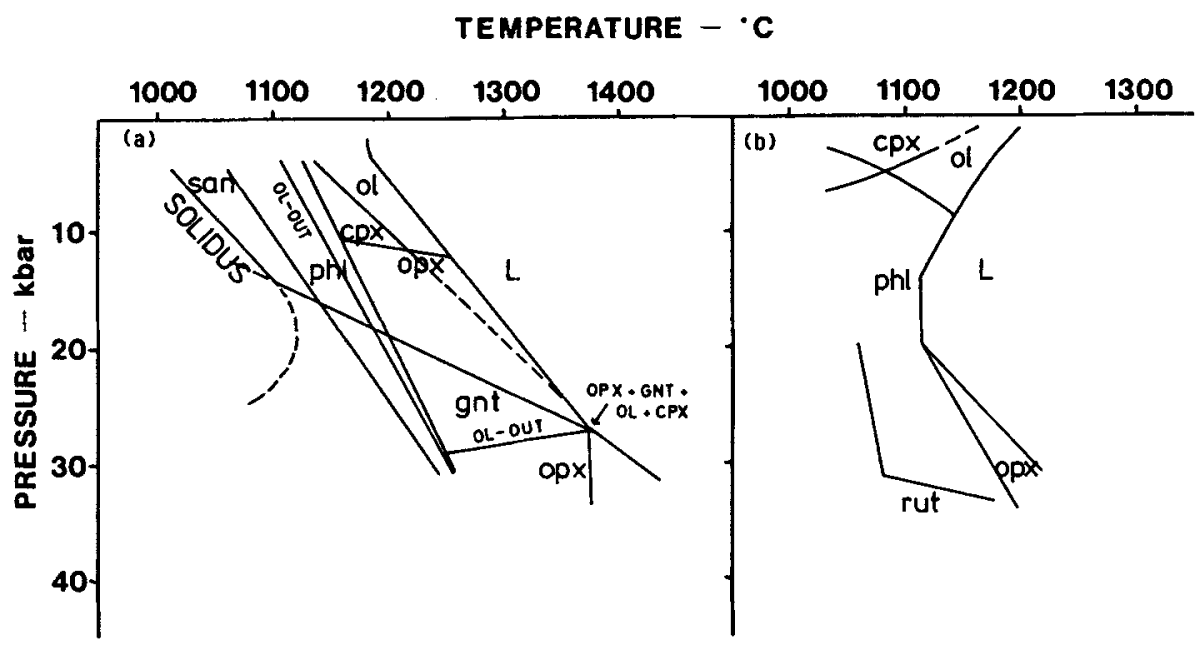

Figure 3. Leucite lamproite liquidus diagrams compared: (a) water-undersaturated phase relationships for a Leucite Hills orendite (after Barton and Hamilton 1982). First appearance of minerals labelled as in figures 1 and 2 . The four-phase lherzolite multiple saturation point is labelled at $27 \mathrm{~kb}$. (b) fluid-present $\left(\mathrm{H}_{2} \mathrm{O} \gg \mathrm{CH}_{4}\right)$ phase relationships for Gaussberg olivine leucitite (after Foley 1989a). See figure 1 for abbreviations.

derived composition than $\mathrm{Mg}$ No. The wolgidite has a very high $\mathrm{TiO}_{2}$ and low $\mathrm{Al}_{2} \mathrm{O}_{3}$ relative to Gaussberg, which is reflected in the appearance of rutile, armacolite and priderite in the experiments with added $\mathrm{H}_{2} \mathrm{O}$. Arima and Edgar (1983a) concluded that wolgidite could not be derived by partial melting of mica-lherzolite, but may be a primitive composition derived from metasomatized mantle containing rutile, mica, orthopyroxene and olivine, but not clinopyroxene. I prefer the explanation that wolgidite is not a primitive composition, but the product of crystal fractionation. The wolgidite experiments would then be interesting for determining fractionation sequences, but it would be misleading to use them as indicators of source mineralogy. Arima and Edgar (1983a) noted that the absence of clinopyroxene is atypical in enriched mantle sources, and ascribed this to low $\mathrm{CaO}$ in the wolgidite source relative to East African enriched mantle samples. However, a lamproite melt is itself a good model for a $\mathrm{CaO}$-poor enriching agent, and near-solidus experiments show that solidification of lamproite melts at $15-30 \mathrm{~kb}$ always produces a mica + clinopyroxene-bearing assemblage (e.g. Barton and Hamilton 1982; Arima and Edgar 1983a; Foley 1989a), showing that an enriched source is unlikely to be clinopyroxene-free.

The high pressure experiments on the Gaussberg leucite lamproite were run under buffered, low $f_{\mathrm{O}_{2}}$ conditions with a fluid which was water-rich with minor $\mathrm{CH}_{4}$. Reducing conditions were suspected from lamproite spinel compositions (Foley 1985; Foley et al 1986a) and general models for reduced mantle conditions (e.g. Green et al 1987). The results, depicted in figure $3 \mathrm{~b}$, show the low pressure liquidus field for olivine and high pressure liquidus field for orthopyroxene which were expected for the suggested mica-harzburgite source, but the intervening liquidus field for mica alone does not fit the theory. The most likely explanation is the excessive amount of water added as an experimental convenience to enable buffering of $f_{\mathrm{O}_{2}}$ : if a smaller amount of water were present, the liquidus would move to higher temperatures, and the 
phlogopite liquidus field would shrink to a point which would be consistent with an incongruently melting phase (Foley 1989a).

The Gaussberg and orendite studies, depicted together in figure 3 for ease of comparison, are at first sight incompatible. The compositions are reasonably similar (the main difference being in $\mathrm{SiO}_{2}$ content and $\mathrm{Mg} \mathrm{No}$.) and yet produce very different results. The higher-silica, quartz-normative orendite appears to have a four-phase lherzolite point at the liquidus at $27 \mathrm{~kb}$, whereas the olivine-normative Gaussberg has no olivine above $5 \mathrm{~kb}$. However, the two studies are comparable if allowance is made for (i) the uncertainty about the presence of olivine in the orendite experiments, and (ii) the differing amounts of $\mathrm{H}_{2} \mathrm{O}$. Barton and Hamilton (1982) opened their discussion with the comment: "One of the major problems in the present study concerned the identification of olivine in the high pressure experiments". Olivine became smaller and rare above $12 \mathrm{~kb}$, and was large enough for microprobe analysis only at $5 \mathrm{~kb}$. If we assume that olivine is stable only at less than $12 \mathrm{~kb}$, where a reaction relationship with orthopyroxene appears (Barton and Hamilton 1982), then the difference in the liquidus relationships can be explained by the Gaussberg experiments having too much water, and the orendite too little. At intermediate $\mathrm{H}_{2} \mathrm{O}$ contents the liquidus temperatures would be comparable. The major effect of adding $\mathrm{H}_{2} \mathrm{O}$ to the orendite would be to expand the phlogopite phase field towards the liquidus due to both greater stability of phlogopite and depression of the liquidus temperature. This would greatly outweigh the promotion of olivine stability in $\mathrm{H}_{2} \mathrm{O}$-rich conditions (Kushiro 1972). A mica + olivine + orthopyroxene point may thus appear at the liquidus of orendite, but certainly at a pressure less than $20 \mathrm{~kb}$. Addition of water would not favour garnet stability, which may then first appear at still higher pressures than $27 \mathrm{~kb}$, suggesting that it is not present in the source of leucite lamproites.

The olivine lamproite experiments (composition 8 in table 1) were also run under reducing, $\mathrm{H}_{2} \mathrm{O}$-rich conditions. The results are shown in figure 4 , where they are optimistically extrapolated to higher pressures, showing that they are consistent with the melting of mica harzburgite at $55 \mathrm{~kb}$ or more. This depth of origin would also agree with the occurrence of diamonds in West Australian olivine lamproites. The compatibility of the Gaussberg and olivine lamproite results with a mica harzburgite source shows that a variety of lamproitic melts may be produced by the melting of the same depleted, and later re-enriched, source with similar volatiles but under different pressures, such that more silica-rich leucite lamproites are derived from lower pressures (Foley 1989a).

Although this appears to offer a comprehensive model for the origin of lamproites, uncertainties remain, particularly as regards oxygen fugacity. An experiment on the Gaussberg composition with higher $f_{\mathrm{O}_{2}}, \mathrm{CO}_{2}$-rich fluid contains clinopyroxene (Foley 1989b). The reduced mica-harzburgite melting model was developed from a simple system without $\mathrm{CaO}$, and so the incoming of clinopyroxene with increasing $\mathrm{CO}_{2}$ indicates that further investigation of the phase volume of clinopyroxene in lamproitic systems is needed. $\mathrm{CO}_{2}$-rich conditions of melting or a clinopyroxene + mica-bearing source may prove to be the key to the genesis of madupitic magmas, which are $\mathrm{CaO}$-richer than most lamproites.

More impression of the effects of $\mathrm{CO}_{2}$ can be gained from experiments on potassic rocks from East Africa and Indonesia (see compositions $G, H, I$ and $K$ in table 2). These normally contain no orthopyroxene near the liquidus whereas clinopyroxene and mica are common with a mixed $\mathrm{H}_{2} \mathrm{O}+\mathrm{CO}_{2}$ volatile phase. An exception is the 


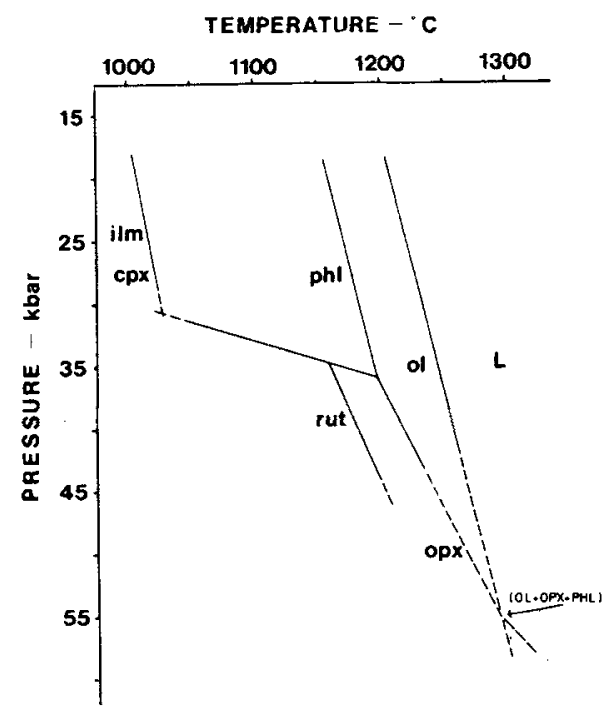

Figure 4. Liquidus phase relationships for an olivine lamproite composition from West Kimberley under fluid-present $\left(\mathrm{H}_{2} \mathrm{O} \gg \mathrm{CH}_{4}\right)$ conditions. Phase relationships were determined to $40 \mathrm{~kb}$ (Foley 1989a), and are extrapolated here to $60 \mathrm{~kb}$ to show that they are consistent with phlogopite-harzburgite partial melting at approximately $55 \mathrm{~kb}$. See figure 1 for abbreviations.

study of Ryabchikov and Green (1978) in which orthopyroxene replaces olivine as the liquidus phase of biotite mafurite at $30 \mathrm{~kb}$ with increasing $\mathrm{CO}_{2} / \mathrm{H}_{2} \mathrm{O}$. In their study of an Indonesian potassic basanite, Nicholls and Whitford (1983) suggested that the stability fields of mica and clinopyroxene were artificially enlarged by interaction of the basanite with wall rocks during ascent. This suggestion is very important in view of the increasing popularity of models for the emplacement of alkaline magmas through a fracture system developed by successive generations of stagnated vein intrusions. This will be discussed further in $\$ 4$.

\subsection{Alkaline and ultramafic lamprophyres}

The only study of a lamprophyre at high pressures is that of an Arizona minette, controlled at two different oxygen fugacities (Esperanca and Holloway 1987). This study produced a mica-wehrlite assemblage close to the liquidus at $17-20 \mathrm{~kb}$, although the liquidus was not mapped out in detail. Esperanca and Holloway (1987) concluded that the results could not distinguish between a reduced ( $\mathrm{Fe}-\mathrm{FeO}$ buffer) and oxidized (QFM buffer) source, nor could they rule out an origin from a garnet-bearing source at pressures greater than $20 \mathrm{~kb}$. The latter origin would be compatible with the occurrence of garnet-lherzolite xenoliths in minettes from this volcanic field (Ehrenberg 1982).

The paucity of experiments on alkaline lamprophyres, and the complete lack of experiments on ultramafic lamprophyres, reflect poor understanding of primary magma compositions. Only rarely does direct evidence of a mantle origin such as the garnet peridotite xenoliths in Arizona minettes exist. Most alkaline lamprophyres are assumed to be crystal fractionation products of basanitic or potassic parental magmas, but too few experimental studies exist to illuminate the problem. 
The ultramafic lamprophyres are normally carbonate-rich and are probably derived from a range of very low silica $\left(<35 \mathrm{wt} \% \mathrm{SiO}_{2}\right)$ magmas. Primary magmas may be related in origin to carbonatites and/or melilitites as low-degree melts of mantle sources. This group of rocks is the victim of semantic difficulties surrounding kimberlites (see Mitchell 1986), having been grouped as 'central complex kimberlites' for several years, and consequently assumed to be of unfathomable complexity as regards petrogenesis. Primary magmas may not be far removed from the range of compositions seen in ultramafic lamprophyre dyke swarms (Upton and Emeleus 1987; Malpas et al 1986), and liquidus studies would certainly be worthwhile. Investigation of carbonate-rich igneous rocks by the reverse approach is a ripe topic following results of greater precision in peridotite melting studies (see $\S 3$ ).

\section{Summary of relevant peridotite partial melting experiments}

There have been numerous partial melting studies on natural and synthetic peridotite compositions over the last 20 years. Many of these have been run under dry conditions and have been aimed at investigating the origin of voluminous basalt types such as mid-ocean ridge basalts; a recent summary is given by Falloon and Green (1988). Volatiles, particularly $\mathrm{H}_{2} \mathrm{O}$ and $\mathrm{CO}_{2}$, appear to be essential to the genesis of the alkaline rocks which are the subject of this paper, and these volatiles cause melting to occur at much lower temperatures than in volatile-free conditions. Volatile-bearing experiments have been undertaken in simple systems and in natural compositions, but the results have not always been compatible and there has been much debate about the composition of very low-degree partial melts. This is particularly due to problems. of quenching which only rarely allow direct analysis of quenched glasses. Simple systems can be theoretically analysed, but the extrapolation of conclusions to complex systems is problematical and invariant points and eutectics become smeared out into 'pseudoinvariant points' and 'pseudoeutectics', which are then interpreted with varying degrees of precision by various authors.

Discussion here will be restricted to examples of melting in volatile-bearing conditions, and to recent experiments in mixed $\mathrm{H}_{2} \mathrm{O}+\mathrm{CO}_{2}$ systems which have helped to sort out many of the differences from earlier studies. This is followed by comments on experiments in non-lherzolitic compositions which have been neglected relative to lherzolites although many are of importance to alkaline rocks.

\subsection{Experiments in lherzolitic systems with $\mathrm{H}_{2} \mathrm{O}$ and $\mathrm{CO}_{2}$}

Figure 5 shows solidus curves for water-saturated and water-undersaturated melting of natural and synthetic peridotite from the studies of Millhollen et al (1974) and Green (1973). The melting curves for water-saturated conditions agree remarkably well and show a large depression of melting temperature when compared to the dry solidus from Takahashi (1986). In water-undersaturated conditions which are more reasonable for the mantle, the solidus moves to higher temperatures and is controlled by the amphibole breakdown curve. Here there are important differences between the solidi which become especially important in mixed $\mathrm{H}_{2} \mathrm{O}+\mathrm{CO}_{2}$ systems. If the mantle solidus corresponds to the dashed solidus of Green (1973) then melting near $1000^{\circ} \mathrm{C}$ will be possible only at pressures of $29 \mathrm{~kb}$ or more, in contrast to lower pressures if the solidus of Millhollen et al (1974) applies. A similar difference in the stability limit 


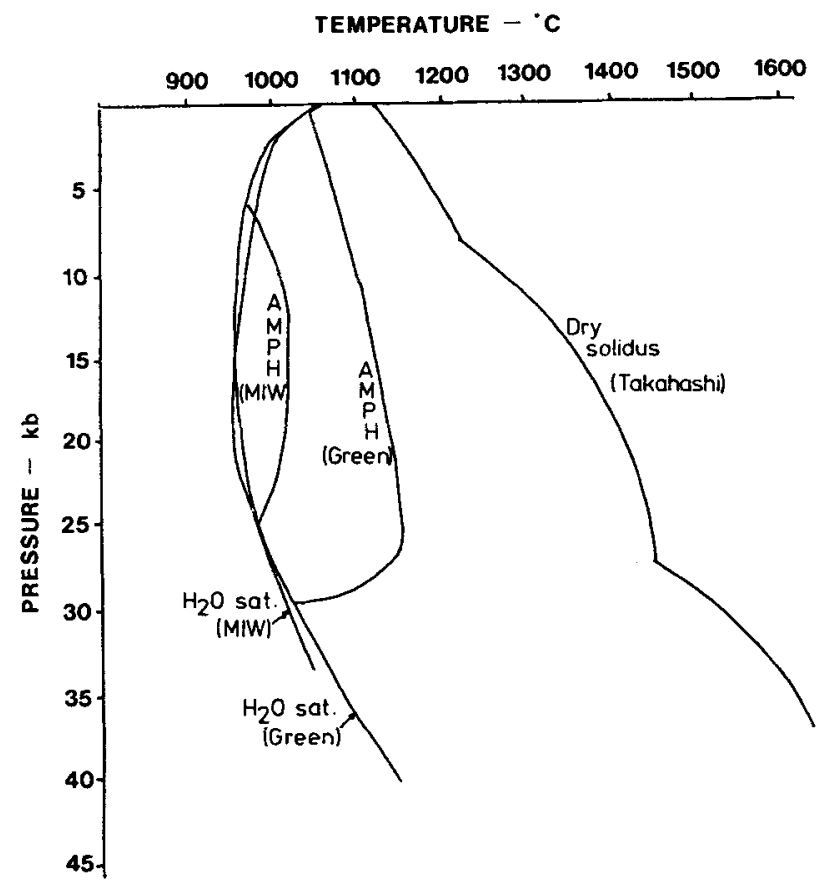

Figure 5. Melting curves for peridotite under dry (Takahashi 1986) and water-bearing conditions. Under water-saturated conditions the curves determined by Green (1973) and Millhollen et al (MIW, 1974) agree very closely. With only very small amounts of water $(<0.4 \mathrm{wt} \%)$ present, melting coincides with the breakdown of amphibole, and the results differ as shown between Green (1973) and Millhollen et al (1974).

of amphibole is seen in $\mathrm{H}_{2} \mathrm{O}+\mathrm{CO}_{2}$ experiments (figure 6) between the results of Olafsson and Eggler (1983) and Wallace and Green (1988). The difference may be related to the alkali content of the starting composition used: in experiments by Green and co-workers, $40 \%$ normative olivine is subtracted from the peridotite composition for the starting mixture, which has the effect of concentrating all components not contained in olivine. Recent experiments have shown alkali-amphiboles to be stable to much higher pressures than pargasites (K-richterites to $>100 \mathrm{~kb}$; Tronnes et al 1988). This olivine subtraction technique appears to be another example of an experimental convenience (olivine was subtracted to enable easier identification and analysis of minor phases) which has to be allowed for in interpretation of results.

The experiments of Olafsson and Eggler (1983) and Wallace and Green (1988) on peridotite $+\mathrm{H}_{2} \mathrm{O}+\mathrm{CO}_{2}$ (figure 6) both show that amphibole and carbonate can exist together at the peridotite solidus. This was a subject of debate from earlier theoretical interpretations which sought to fit decarbonation reactions from simple systems (especially CMS- $\mathrm{CO}_{2}$ ) with the different amphibole breakdown curves from figure 5 (see Wyllie 1978). The curves shown are for peridotite with only minor amounts of $\mathrm{H}_{2} \mathrm{O}$ and $\mathrm{CO}_{2}$. Water was present in excess of that needed to hydrate all potential amphibole, whereas insufficient $\mathrm{CO}_{2}$ was present to form all potential carbonate. Thus there should be a fluid present in the experiments, which should cause restriction of the melting reaction to a univariant curve, meaning that at each pressure only a single initial melt composition could form. These solidus-buffering principles were 


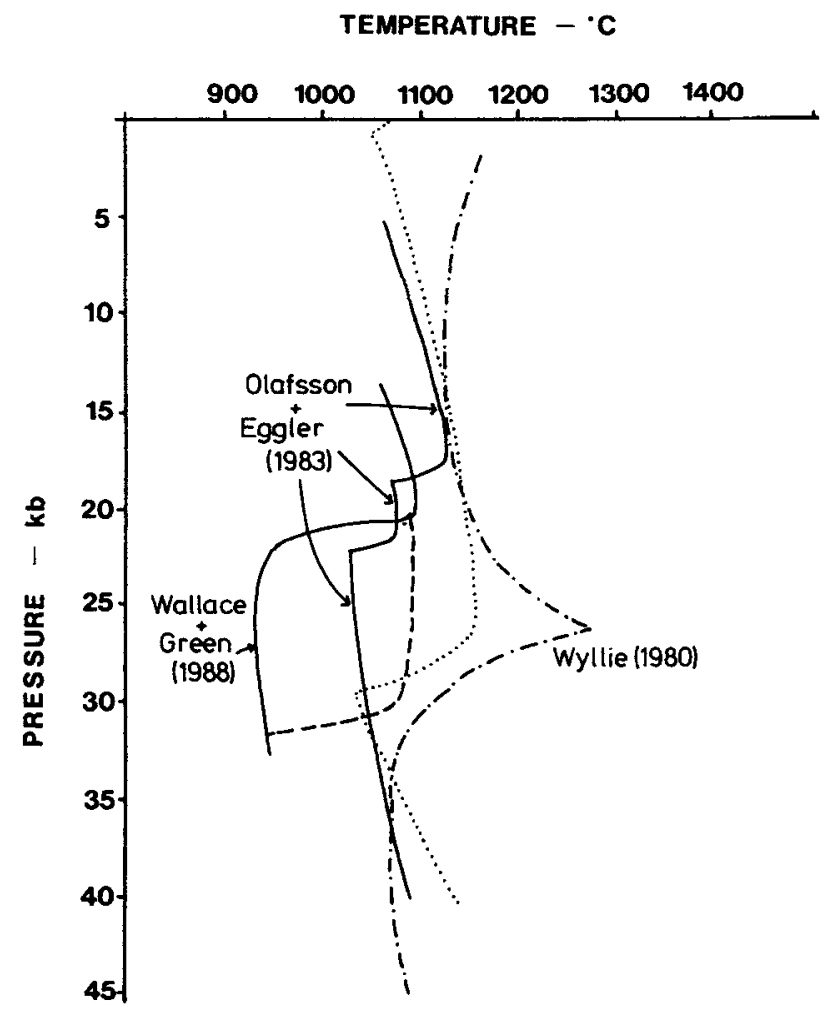

Figure 6. Experimental and theoretical melting curves for peridotite with mixed $\mathrm{H}_{2} \mathrm{O}+\mathrm{CO}_{2}$ in small amounts. The experimental curves of Olafsson and Eggler (1983) and Wallace and Green (1988) differ appreciably, probably due to (i) exaggerated stability of amphibole in the study of Wallace and Green (shown by the dashed line), and (ii) recognition of soluble Na-carbonate melt patches by Wallace and Green. The dash-dot line shows a theoretical solidus derived by Wyllie (1980) from simple system constraints before the peridotite experiments were done. The dotted line shows the water-undersaturated peridotite melting curve of Green (1973) from figure 5 for reference.

developed theoretically from simple systems (see Eggler and Holloway 1977; Wyllie 1978), but the extent to which they apply to natural compositions is not yet clear.

The results of Wallace and Green (1988) differ from those of Olafsson and Eggler (1983) in two important respects: (i) the stability of amphibole, as discussed above, which appears well above the solidus curve according to Wallace and Green, and (ii) the much lower solidus temperature at pressures above $22 \mathrm{~kb}$. Wallace and Green considered that this low temperature melting interval was missed in earlier studies due to dissolution of sodium carbonate-rich melt pockets in water during preparation of sections for analysis.

The composition of near-solidus melts, buffered or not, is much debated since they are generally unquenchable, and there are diverse opinions about the best method of estimating compositions of the first-formed melts. Estimates can be made by; (i) direct measurement of glass compositions by microprobe, which loses accuracy where abundant crystal growth occurs during the quench, (ii) calculation of melt composition by mass balance following an estimate of modal abundance of phases present, (iii) extrapolation from simple system melt compositions and phase boundary 
dependence on volatile speciation, and most recently (iv) reversal of estimated melt compositions by re-equilibration with peridotite using the 'sandwich' technique. Method (iv) was used by Wallace and Green (1988), who obtained a soda-carbonatite melt composition by a sequence of iterative sandwich experiments. The estimated composition from method (ii) was run as a sandwich layer between two peridotite layers, and allowed to re-equilibrate at a temperature and pressure just above the peridotite solidus $\left(22 \mathrm{~kb}, 1000^{\circ} \mathrm{C}\right)$. The composition of the melt layer from this experiment was then used as the starting composition of the sandwich layer for the next experiment, and the sequence was continued until minerals in the peridotite layers matched those in the original experiment.

The sandwich method provides a useful tool for further investigation of nearsolidus melts in the future. Careful reversal of near-solidus melt composition is needed for $\mathrm{H}_{2} \mathrm{O}$ and mixed $\mathrm{H}_{2} \mathrm{O}+\mathrm{CO}_{2}$ compositions at various pressures, since the compositions are only very generally constrained. From simple system experiments with $\mathrm{CO}_{2}$ at pressures of $25-30 \mathrm{~kb}$, Wyllie and Huang (1975) interpreted the first melts to be carbonatitic, whereas Eggler (1976) said they were carbonate-rich silicate liquids with about $30 \mathrm{wt} \% \mathrm{SiO}_{2}$. This difference of opinion continues into studies of simple and complex systems with $\mathrm{CO}_{2}$ and mixed $\mathrm{H}_{2} \mathrm{O}+\mathrm{CO}_{2}$ volatiles, with both carbonatite (e.g. Wendlandt and Mysen 1980) and carbonate-rich silicate liquids, either as melilitites (e.g. Brey 1978; Brey et al 1983) or possibly ultramafic lamprophyretype melts (Wyllie and Huang 1976), finding favour with different investigators. Greater pressure should cause lower silica contents in melts, resulting in larnitenormative chemistry, a feature of kimberlites (e.g. Wyllie 1978). The high $\mathrm{Mg} / \mathrm{Ca}$ of kimberlite relative to melilitite may be explained by magnesite, (which is stable at the solidus of lherzolite about $40 \mathrm{~kb}$ and above) rather than dolomite, being the carbonate involved in the melting reaction (Brey 1978).

\subsection{Experiments in non-lherzolitic systems}

There have been relatively few experimental studies of systems designed to interpret melting in non-lherzolitic compositions, and most of these have been in simple systems. We are particularly interested here in the work on mica-bearing mineral assemblages which are relevant to potassic rocks, at least some of which are likely to leave residual mica in their source regions. Work in simple and complex systems has shown that mica coexisting with orthopyroxene and/or clinopyroxene melts incongruently to olivine + liquid, or possibly olivine + garnet + liquid at higher pressures (Modreski and Boettcher 1972, 1973; Wendlandt and Eggler 1980). Mica also melts incongruently when it is very fluorine-rich (Foley et al 1986b). Melts produced from mica-bearing assemblages are thus peritectic, and lie to silica-richer compositions than pure mica, as shown in figure 7a. This figure also shows the effect of different volatile species on the $\mathrm{Phl}+\mathrm{Opx}+\mathrm{Ol}+\mathrm{L}$ peritectic melting point, as indicated by the relative phase volumes of olivine and orthopyroxene.

Lamproites are most likely formed in $\mathrm{H}_{2} \mathrm{O}$ - and $\mathrm{HF}$-rich, and $\mathrm{CO}_{2}$-poor environments, which result in a similar position for the peritectic point to that in the $\mathrm{H}_{2} \mathrm{O}$-rich system in figure $7 \mathrm{a}$. The effect of pressure on the position of the peritectic point in $\mathrm{H}_{2} \mathrm{O}$-rich conditions is shown in figure $7 \mathrm{~b}$ as constrained by the liquidus experiments on Gaussberg and the West Kimberley olivine lamproite (Foley 1989a). The melts vary from $\mathrm{K}-$, Si-rich and relatively $\mathrm{Mg}$-poor at pressures of $15-20 \mathrm{~kb}$ 

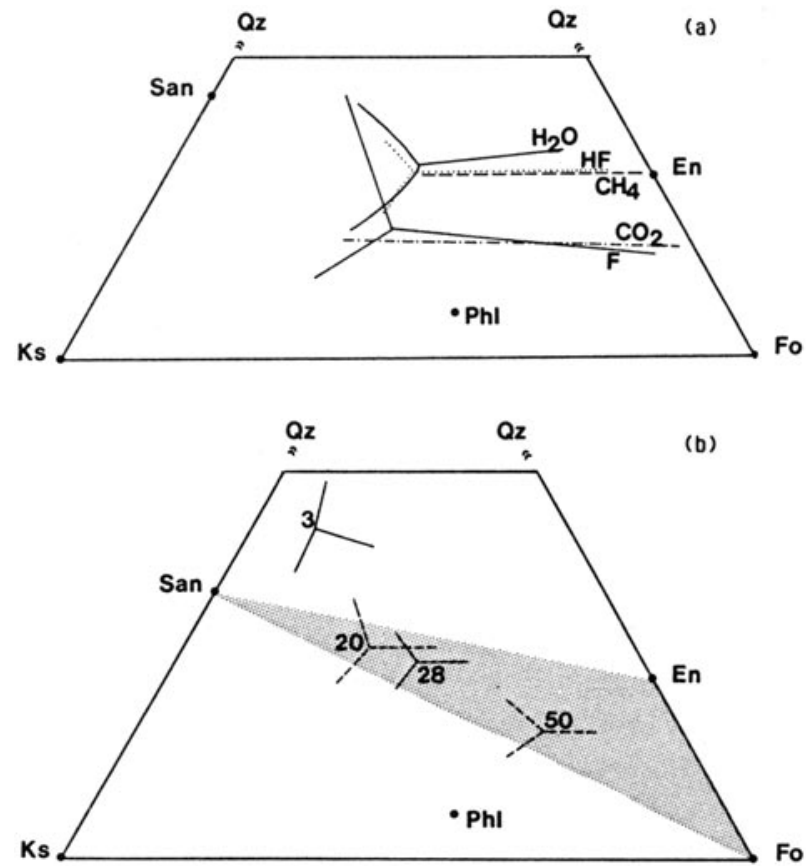

Figure 7. Sections of the system kalsilite-forsterite-quartz showing positions of the peritectic melting point $\mathrm{Phl}+\mathrm{Ol}+\mathrm{Opx}+\mathrm{L}$ in various volatile conditions (a) and various pressures (b). Curves in (a) are experimentally determined positions for either the peritectic point or the enstatite-forsterite cotectic except for $\mathrm{HF}$ and $\mathrm{CH}_{4}$ which are estimated positions. Positions in (b) are determined in $\mathrm{H}_{2} \mathrm{O}$-saturated conditions for $3 \mathrm{~kb}$ (Luth 1967) and $28 \mathrm{~kb}$ (Gupta and 'Green 1989), whereas positions for $20 \mathrm{~kb}$ and $50 \mathrm{~kb}$ are projected positions for leucite- and olivine-lamproite indicating their approximate pressures of origin consistent with liquidus relationships given in figures 3 and 4 . The shaded zone is between the critical planes of oversaturation and undersaturation, indicating that peritectic melts from mica harzburgite are hypersthene-normative even at $50 \mathrm{~kb}$. See figure 1 for abbreviations.

(leucite lamproite), to higher $\mathrm{Mg}$, lower $\mathrm{K}, \mathrm{Si}$ (but still hypersthene normative; olivine lamproite) at pressures of about $50 \mathrm{~kb}$. These positions for the peritectic point must be approximately correct for mica-harzburgite mineralogy (and thus probably for lamproite source regions), but in Ca- and Al-richer (i.e. less depleted) source regions, phase volumes for clinopyroxene and garnet may interfere. This is demonstrated by the appearance of garnet as an incongruent melting product of Al-richer mica-bearing assemblages (Modreski and Boettcher 1973), and by the possible importance of clinopyroxene in lamproites in higher $f_{\mathrm{O}_{2}}$ conditions (see $\S 2$ ).

Melt compositions in 'fertile' mica-bearing compositions with $\mathrm{CO}_{2}$ are thought to be carbonatitic or kimberlitic, but melt compositions in melting experiments have generally not been measured due to problems of quench (e.g. Wendlandt 1984), and can only be estimated from phase relationships and abundances.

Lloyd et al (1985) melted an olivine-free nodule in which mica and clinopyroxene together constitute $85 \%$ modally. From experiments with no added volatiles they concluded that partial melts were $\mathrm{K}$-rich $\left(\mathrm{K}_{2} \mathrm{O} 4-6 \mathrm{wt} \%\right)$, CaO-rich $(10-14 \mathrm{wt} \%)$, and $\mathrm{Al}_{2} \mathrm{O}_{3}$-poor $(8-9 \mathrm{wt} \%)$ to degrees of melting in excess of $20 \%$, showing the importance of the abundance of mica in the source. The $\mathrm{Mg} \mathrm{No}$. of the melts was around 60, which 
is much lower than the 70 generally taken to indicate a primary mantle-derived melt. This emphasizes that criteria used to identify primary basaltic magmas may be misleading for unusual alkaline rocks which may be derived from sources with nonlherzolitic mineralogy.

\section{Synthesis: Experimental constraints on the genesis of lamproites, kimberlites and lamprophyres}

The origin of most lamproites appears to be explainable by the partial melting of mica harzburgite in which mica remains residual in the source. This origin is supported by experiments in simple systems on model source compositions, and liquidus relationships of lamproites are compatible when volatile compositions in experiments are $\mathrm{H}_{2} \mathrm{O}$ - and $\mathrm{HF}$-rich, with little or no $\mathrm{CO}_{2}$. The temperature of the $\mathrm{Phl}+\mathrm{Opx}+$ $\mathrm{Ol}+\mathrm{L}$ peritectic melting point in the system kalsilite-forsterite - silica is $300^{\circ} \mathrm{C}$ higher in the fluorine-bearing, $\mathrm{H}_{2} \mathrm{O}$-free system than in water-saturated conditions (Foley et al 1986), showing fluorine-rich micas to be thermally much more stable than hydroxymicas. This means that micas containing $\mathrm{F}+\mathrm{OH}$ will remain stable during melting by a 'sliding reaction' in which $\mathrm{F} / \mathrm{OH}$ of the mica increases with increasing degree of partial melting, and so the presence of fluorine-rich mica in the solid residue after partial melting is to be expected.

Further support for this model comes from mica compositions in the lamproite liquidus studies, which show that micas poor in $\mathrm{Al}_{2} \mathrm{O}_{3}$, which are typical of natural lamproites, are characteristic of low $\alpha_{2} \mathrm{O}$, F-rich conditions (Foley 1989b). Melting of micas with high $\mathrm{F} / \mathrm{OH}$ thus contribute a perpotassic $(\mathrm{K} / \mathrm{Al} \gg 1)$ component to the melt, whereas micas with low $\mathrm{F} / \mathrm{OH}$ would be Al-rich and cannot lead to melts with $\mathrm{K} / \mathrm{Al} \gg 1$. Melting of F-rich, Al-poor mica thus accounts for the previously enigmatic perpotassic chemistry which is peculiar to lamproites, and obviates the need for explanations such as high pressure fractionation of an alumina-rich phase in order to increase the $\mathrm{K} / \mathrm{Al}$ in the melt (e.g. Sheraton and Cundari 1980). Since the source mica must be F-rich and Al-poor, this constrains the enrichment event, which introduces silicate-incompatible elements to overprint the $\mathrm{Al}$-, $\mathrm{Na}$-, and $\mathrm{Ca}$-depleted chemistry.of the source, to be a low $\alpha \mathrm{H}_{2} \mathrm{O}$ event: the later partial melting event which produces the lamproitic magma could be water-rich (Foley 1989b).

While both olivine lamproites and leucite lamproites can be fit into this general scheme of mica-harzburgite melting, several points remain in question, such as how silica-rich primary leucite lamproites can be, and if it is possible to derive a lamproite by the melting of a clinopyroxene-rich source. Barton and Hamilton (1982) doubted that the orendite with $55 \mathrm{wt} \% \mathrm{SiO}_{2}$ could be derived from a therzolitic source, but suggested that olivine orendites, which are olivine normative despite $53 \mathrm{wt} \% \mathrm{SiO}_{2}$ (Kuehner et al 1981), could originate by the melting of mica-garnet lherzolite at pressures of about $27 \mathrm{~kb}$. However, since the effect of extra water on the phase relationships of orendite would be to expand the phase volumes of olivine and mica, and to move garnet to higher pressures, the interesting pressure region then becomes $10-20 \mathrm{~kb}$, where olivine, mica, orthopyroxene, and possible clinopyroxene could then be near-liquidus phases. This makes the orendite and Gaussberg experiments compatible with a mica-harzburgite or mica-lherzolite source which is garnet-free. The pressure of origin for the Gaussberg composition, as measured by the 
probable location of the $\mathrm{Ol}+\mathrm{Opx}+\mathrm{Phl}$ point at the liquidus with less water than in the experiments depicted in figure $3 \mathrm{~b}$, is approximately $17-20 \mathrm{~kb}$. Silica-richer partial melts could be derived by the melting of a similar source at lower pressures, in which high $\mathrm{SiO}_{2}$ contents would be promoted by $\mathrm{H}_{2} \mathrm{O}$-rich conditions and the incongruent melting of both mica and enstatite. The approximate composition of such melts at uppermost mantle pressures such as $8-10 \mathrm{~kb}$ can be estimated by interpolating between the positions for the peritectic melting points for $28 \mathrm{~kb}$ and $3 \mathrm{~kb}$ (from Luth 1967) in figure $7 \mathrm{~b}$. The predominance of silica-rich, but apparently primitive, leucite lamproite compositions in Southeastern Spain may be due to very shallow melting (Foley and Venturelli 1989).

The effect of $\mathrm{CO}_{2}$ on lamproite phase relationships remains to be fully investigated although it appears to cause rapid expansion of the clinopyroxene phase volume. While a major role for $\mathrm{CO}_{2}$ is precluded for most lamproites by their very low $\mathrm{CO}_{2}$ contents, it may be important for clinopyroxene-rich examples such as the Leucite Hills madupites and the West Greenland lamproites. These madupitic lamproites are $\mathrm{CaO}$-rich (see table 1, composition 5) and are much more similar to the Group II ultrapotassic rocks of East Africa, for which an origin with mixed $\mathrm{CO}_{2}+\mathrm{H}_{2} \mathrm{O}$ appears to be required (Ryabchikov and Green 1978; Edgar et al 1980; Arima and Edgar 1983b). The coexistence of madupitic and leucite lamproites in the same volcanic field, as in the Leucite Hills, may be due to the melting of mantle regions with different oxidation states, where clinopyroxene is much more common in the more oxidized, $\mathrm{CO}_{2}$-bearing regions (Foley 1988).

Attempts to constrain the origin of kimberlites with experiments have concentrated on melting studies of mantle peridotite. Despite many years of melting studies, initial melt compositions of lherzolite at various pressures are not sufficiently constrained to ascertain exactly what type of melt would be produced. This is mainly due to the difficulty of analysing melt compositions, for which reversal experiments using the 'sandwich' technique are likely to provide considerable advances in the next few years.

Theoretical treatments of simple systems bearing on hydrous and carbonate minerals (e.g. Eggler 1973; Eggler and Holloway 1977; Wyllie 1978) suggested that the principles of melting in these systems should hold for natural compositions. Experimental studies on natural systems were then said to support this supposition (e.g. Holloway and Eggler 1976; Wendlandt and Mysen 1980) where the results were not contradictory, but were too widely spaced in pressure and temperature to provide a well-constrained test. The effect of solid solutions in complex systems was thought to blur out the melting interval over $5-10^{\circ} \mathrm{C}$ only (Holloway and Eggler 1976), but with no significant change in the melting principles. The impression was gained that mantle peridotite with $\mathrm{CO}_{2}$ and $\mathrm{H}_{2} \mathrm{O}$ melts along a univariant curve with a buffered vapour composition (compromised to a 'pseudounivariant curve' for natural systems), and that future experiments would just need to determine the composition of the buffered liquid compositions as a function of pressure. The current lack of constraint on liquid compositions is shown by the fact that the same range of melts is discussed for solidi as widely differing as the theoretical example of Wyllie (1980) and the experimental solidi from complex compositions of Olafsson and Eggler (1983) and Wallace and Green (1988) (figure 2).

This lack of specificity in partial melt compositions may be partly responsible for the lack of progress in understanding kimberlite genesis from experiments. A negative result in terms of partial melt compositions when compared to alkaline basic rock 
compositions may be more useful than a positive one, as noted by Wyllie (1987), but for liquidus experiments. Greater specificity may have deflected interest in the direction of non-lherzolitic compositions, which have recently been suggested by studies of mantle nodules and alkaline rock compositions such as lamproites.

The melting of non-lherzolitic mantle compositions has been largely neglected apart from the consideration of buffered solidi containing phlogopite or amphibole and dolomite or magnesite in addition to the 'normal' four lherzolite minerals olivine, orthopyroxene, clinopyroxene and garnet. The reasons are largely historical, petrologists having been interested in explaining the origin of abundant basaltic rocks in terms of the melting of the presumed most common mantle mineral assemblages (see Wyllie et al 1981 for a review). The underlying assumptions that all mantlederived rocks fit equilibrium with lherzolite are preserved in the general acceptance of criteria such as $\mathrm{Mg}$ No. $\geqslant 70$ to indicate a primitive liquid. The behaviour of mantle mineral assemblages during partial melting may differ from lherzolite and from the models of hydrous- and carbonate-mineral bearing lherzolite. Solid solution effects have been assumed to be insignificant, but may in some cases be important; the F/OH ratio of mica greatly affects its stability and could cause mica to be much more stable than generally assumed in theoretical models.

The two liquidus experimental studies on kimberlite highlight the problem in defining primitive kimberlite magma compositions, especially with regard to $\mathrm{SiO}_{2}$ and $\mathrm{CO}_{2}$ contents. The calcite-rich kimberlite of Wesselton could not have been formed in a lherzolitic mantle, but more likely in an orthopyroxene-free environment (Edgar et al 1988). The Lesotho kimberlite has olivine, orthopyroxene, clinopyroxene and garnet near its liquidus at $55-60 \mathrm{~kb}$, but magnesite is restricted to much lower temperatures, showing that this composition cannot be a product of melting entirely at a buffered solidus of a carbonate-bearing peridotite, but possibly of lherzolite in which all carbonate was eliminated.

Many kimberlites have much more $\mathrm{CO}_{2}$ than the composition used by Eggler and Wendlandt (1979), and show a strong corelation of $\mathrm{CaO}$ and $\mathrm{CO}_{2}$ contents, which may be due to addition of calcite either at source (e.g. Bailey 1984) or by contamination at later stages (e.g. Brey 1978). Explanations for this hybrid nature of kimberlite include mixing of kimberlitic liquid with shallower-derived carbonatitic liquid (Boyd and Nixon 1973), fluid interaction at the time of melting, or preferential melting of previously solidified magmatic material in veins (e.g. Bailey 1984). Experimental work on alkaline melt compositions has suggested that the reaction of these compositions with peridotite tends to eliminate olivine and orthopyroxene and to promote the stability of clinopyroxene and mica (Nicholls and Whitford 1983, Meen 1987, Wallace and Green 1988, Meen et al 1989). This general rule is supported by studies of veined peridotite xenoliths (e.g. Irving 1980), and applies to the solidification of carbonatitic, carbonate-rich silicate, lamproitic and basanitic magmas. Future experiments should attempt to define the differences in assemblages which result in each case, since they may be important in controlling later partial melt compositions.

The non-lherzolitic component in kimberlites, if just a part, may thus be derived from the partial melting of wall assemblages which are themselves derived from earlier magmatic activity. This may be through assimilation as the melt moves through 'coated' fractures towards the surface, or by the initial melting in veins which then proceeds to involve surrounding lherzolite. Calcite may be the stable carbonate 
phase in clinopyroxene-rich vein assemblages which do not contain orthopyroxene. An interesting possibility for the origin of the calcitic component is the partial melting of eclogitic pods in the presence of $\mathrm{CO}_{2}$. Treiman and Essene (1983) calculated that calcite should be stable in eclogite and that the solidus of eclogite $+\mathrm{CO}_{2}$ should be lower than that of peridotite, but this suggestion has yet to be tested experimentally. Derivation of the calcitic component from an eclogitic source could take place at depths comparable to the generation of the bulk of the kimberlite melt (often around 180 and $200 \mathrm{~km}$ ).

Future experimental investigations will have to proceed in tandem with advances in the understanding of the separability of low-degree partial melts, which is currently the subject of much attention. Further, geophysical studies of the pressure and temperature effects on deformability of mantle materials should help to constrain the upper pressure limit of interest to experiments on vein assemblages, which should be restricted to depths where brittle fracture can occur. At deeper levels, where minerals are much more deformable, pre-concentration of incompatible elements in veins is less likely, but very low degree melts are more likely to move from their sources. Viscosities of various low-degree melts may differ appreciably due to differences in contents of alkalies, $\mathrm{H}_{2} \mathrm{O}, \mathrm{CO}_{2}$ and $\mathrm{F}$, and thus some initial melts may move from their sources sooner than others.

\section{Acknowledgements}

This paper is dedicated to the late Sir C V Raman, on the occasion of his birth centenary.

\section{References}

Arima M and Edgar A D 1983a A high pressure experimental study on a magnesian-rich leucite-lamproite from the West Kimberley area, Australia: petrogenetic implications; Contrib. Mineral. Petrol. 84 228-234

Arima M and Edgar A D 1983b High pressure experimental studies on a katungite and their bearing on the genesis of some potassium-rich magmas of the West Branch of the African Rift; J. Petrol. 24 166-187

Atkinson W J, Hughes F E and Smith C B 1984 A review of the kimberlitic rocks of Western Australia. In Kimberlites I: Kimberlites and related rocks (ed.) J Kornprobst (Amsterdam: Elsevier) pp. 195-224

Bailey D K 1984 Kimberlite: "The mantle sample" formed by ultrametasomatism. In Kimberlites I: Kimberlites and related rocks (ed.) J Kornprobst (Amsterdam: Elsevier) pp. 323-333

Barton M 1976 Melting relations of some ultrapotassic volcanic rocks; Progr. Exp. Petrol. (NERC) 391-94

Barton M and Hamilton D L 1978 Water-saturated melting relations to 5 kilobars of three Leucite Hills lavas; Contrib. Mineral. Petrol. 66 41-49

Barton M and Hamilton D L 1979 The melting relationships of a madupite from the Leucite Hills, Wyoming, to $30 \mathrm{~Kb}$; Contrib. Mineral. Petrol. 69 133-142

Barton $M$ and Hamilton D L 1982 Water-undersaturated melting experiments bearing upon the origin of potassium-rich magmas; Min. Mag. 45 267-278

Bergman S 1987 Lamproites and other potassium-rich igneous rocks: a review of their occurrence, mineralogy and geochemistry. In Alkaline igneous rocks (ed.) J G Fitton and B G J Upton (Geol. Soc. London Spec. Publ.) 30 103-190

Boyd F R, Nixon P H 1973 Origin of the ilmenite-silicate nodules in kimberlites from Lesotho and South Africa. In Lesotho Kimberlites (ed.) P H Nixon (Lesotho National Devt. Corp., Maseru, Lesotho) pp. 254-268

Brey G P 1978 Origin of olivine melilitites - chemical and experimental constraints; J. Volcanol. Geotherm. Res. 3 61-88 
Brey G P, Brice W R, Ellis D J, Green D H, Harris K L and Ryabchikov I D 1983 Pyroxene-carbonate reactions in the upper mantle; Earth Planet. Sci. Lett. 62 63-74

Carmichael I S E 1967 The mineralogy and petrology of the volcanic rocks from the Leucite Hills, Wyoming; Contrib. Mineral. Petrol. 15 24-66

Cundari A and O'Hara M J 1976 Experimental study at atmospheric and high pressures of a mafic leucitite from New South Wales, Australia; Progr. Exp. Petrol. (NERC) 3 260-261

Dawson J B 1980 Kimberlites and their xenoliths (New York: Springer) pp. 250

Edgar A D, Arima M, Baldwin D K, Bell D R Shee S R, Skinner E M W and Walker E C 1988 High pressure-high temperature melting experiments on $\mathrm{a} \mathrm{SiO}_{2}$-poor aphanitic kimberlite from the Wesselton mine, Kimberley, South Africa; Am. Mineral. 73 524-533

Edgar A D and Condliffe E 1978 Derivation of K-rich ultramafic magmas from a peridotitic mantle source; Nature (London) $275639-640$

Edgar A D, Condliffe E, Barnett R L and Shirran R J 1980 An experimental study of an olivine ugandite magma and mechanisms for the formation of its K-enriched derivatives; J. Petrol. 21 475-497

Edgar A D, Green D H and Hibberson W O 1976 Experimental petrology of a highly potassic magma; J. Petrol. 17 339-356

Eggler D H 1973 Principles of melting of hydrous phases in silicate melt; Carnegie Inst. Washington, Yearb. 72 491-495

Eggler D H 1976 Does $\mathrm{CO}_{2}$ cause partial melting in the low-velocity layer of the mantle? Geology 469-72

Eggler D H and Holloway J R 1977 Partial melting of peridotite in the presence of $\mathrm{H}_{2} \mathrm{O}$ and $\mathrm{CO}_{2}$ : principles and review. In Magma Genesis (ed.) H J B Dick (Oregon Dept. Geol. Min. Industries Bull) 96 15-36

Eggler D H and Wendlandt R F 1978 Phase relations of a kimberlite composition; Carnegie Inst. Washington, Yearb. 77 751-756

Eggler D H and Wendlandt R F 1979 Experimental studies on the relationship between kimberlite magmas and partial melting of peridotite. In Kimberlites, diatremes and diamonds: their geology, petrology, and geochemistry (ed.) F R Boyd and H O A Meyer (American Geophysical Union, Washington, U.S.A.) pp. $330-338$

Ehrenberg S N 1982 Rare earth element geochemistry of garnet lherzolite and megacrystalline nodules from minette of the Colorado Plateau province; Earth Planet. Sci. Lett. 57 191-210

Esperanca S and Holloway J R 1987 On the origin of some mica-lamprophyres: experimental evidence from a mafic minette; Contrib. Mineral. Petrol. 95 207-216

Falloon T J and Green D H 1988 Anhydrous partial melting of peridotite from 8 to $35 \mathrm{~kb}$ and the petrogenesis of MORB; $J$. Petrol. Special Lithosphere Issue 379-414

Foley S F 1985 The oxidation state of lamproitic magmas; Tschermaks Mineral. Petrogr. Mitt. 34 217-238

Foley S F 1988 The genesis of continental basic alkaline magmas - an interpretation in terms of redox melting; J. Petrol. Special Lithosphere Issue 139-161

Foley S F 1989a The genesis of lamproitic magmas in a reduced, fluorine-rich mantle. In Kimberlites and related rocks -1 their composition, occurrence, origin and emplacement (ed) A L Jaques, J Ferguson and D H Green (Blackwells, Melbourne) pp. 616-632

Foley S F 1989b Experimental constraints on phlogopite chemistry in lamproites: 1. the effect of water activity and oxygen fugacity; Eur. J. Mineral. 1 pp. 411-426

Foley S F, Taylor W R and Green D H 1986a The role of fluorine and oxygen fugacity in the genesis of the ultrapotassic rocks; Contrib. Mineral. Petrol. 94 183-192

Foley S F, Taylor W R and Green D H 1986b The effect of fluorine on phase relationships in the system $\mathrm{KAISiO}_{4}-\mathrm{Mg}_{2} \mathrm{SiO}_{4}-\mathrm{SiO}_{2}$ at $28 \mathrm{kbar}$ and the solution mechanism of fluorine in silicate melts; Contrib. Mineral. Petrol. 93 46-55

Foley S F and Venturelli $\mathrm{G} 1989$ High $\mathrm{K}_{2} \mathrm{O}$ rocks with high $\mathrm{MgO}$, high $\mathrm{SiO}_{2}$ affinities. In Boninites and related rocks (ed.) A J Crawford (Unwin-Hyman, London) pp. 72-88.

Foley S F, Venturelli G, Green D H and Toscani L 1987 The ultrapotassic rocks: characteristics, classification, and constraints for petrogenetic models; Earth Sci. Rev. 24 81-134

Green D H 1973 Experimental melting studies on a model upper mantle composition at high pressure under water-saturated and water-undersaturated conditions; Earth Planet. Sci. Lett. 19 37-53

Green D H, Falloon T J and Taylor W R 1987 Mantle-derived magmas - roles of variable source peridotite and variable $\mathrm{C}-\mathrm{H}-\mathrm{O}$ fluid compositions. In Magmatic processes: physicochemical principles (ed.) B O Mysen (Geochemical Society Spec. Publ. 1) pp. 139-154

Gupta A K and Green D H 1989 The liquidus surface of the system forsterite-kalsilite-quartz at $28 \mathrm{kbar}$ under dry conditions, in the presence of $\mathrm{H}_{2} \mathrm{O}$, and of $\mathrm{CO}_{2} ;$ Mineral Petrol. 39 163-174 
Holloway J R and Eggler D H 1976 Fluid-absent melting of peridotite containing phlogopite and dolomite; Carnegie Inst. Washington, Yearb. 75 636-639

Irving A J 1980 Petrology and geochemistry of composite ultramafic xenoliths in alkalic basalts and implications for magmatic processes within the mantle; Am. J. Sci. A280 389-426

Jaques A L, Lewis J D, Smith C B, Gregory G P, Ferguson J, Chappell B W and McCulloch M T 1984 The diamond-bearing ultrapotassic (lamproitic) rocks of the West Kimberley region, Western Australia. In Kimberlites 1: Kimberlites and related rocks (ed.) J Kornprobst (Amsterdam: Elsevier) pp. 225-254

Jaques A L, Lewis J D and Smith C B 1986 The kimberlites and lamproites of Western Australia; Geol. Surv. West. Aust. Bull. 132 pp. 268

Kuehner S M, Edgar A D and Arima M 1981 Petrogenesis of the ultrapotassic rocks from the Leucite Hills, Wyoming; Am. Mineral. 66 663-677

Kushiro 11972 Effect of water on the compositions of magmas formed at high pressure; J. Petrol. 13 311-334

Lloyd F E, Arima M and Edgar A D 1985 Partial melting of a phlogopite-clinopyroxenite nodule from South-West Uganda: an experimental study bearing on the origin of highly potassic continental rift volcanics; Contrib, Mineral. Petrol 91 321-329

Luth W C 1967 Studies in the system $\mathrm{KAISiO}_{4}-\mathrm{Mg}_{2} \mathrm{SiO}_{4}-\mathrm{SiO}_{2}-\mathrm{H}_{2} \mathrm{O}$ : I, inferred phase relations and petrologic applications; J. Petrol. 8 372-416

Malpas J, Foley S F and King A F 1986 Alkaline mafic and ultramafic lamprophyres from the Aillik Bay area, Labrador; Can. J. Earth Sci. 23 1902-1918

Meen J K 1987 Mantle metasomatism and carbonatites, an experimental study of a complex relationship; Geol. Soc. Am. Spec. Pap. 215 91-100

Meen J K, Ayers J C and Fregeau E J 1989 A model of mantle metasomatism by carbonated alkaline melts: trace-element and isotopic compositions of mantle source regions of carbonatite and other continental igneous rocks. In Carbonatites (ed.) K Bell (Unwin-Hyman) pp. 464-499

Millhollen G L, Irving A J and Wyllie P J 1974 Melting interval of peridotite with 5.7 per cent water to 30 kilobars; $J$. Geol. 82 575-587

Mitchell R H 1986 Kimberlites: mineralogy, geochemistry, and petrology (New York: Plenum) pp. 442

Modreski P J and Boettcher A L 1972 The stability of phlogopite + enstatite at high pressures: a model for micas in the interior of the Earth; Am. J. Sci. $272852-869$

Modreski P $J$ and Boettcher A L 1973 Phase relationships of phlogopite in the system $\mathrm{K}_{2} \mathrm{O}-\mathrm{MgO}-$ $\mathrm{CaO}-\mathrm{Al}_{2} \mathrm{O}_{3}-\mathrm{SiO}_{2}-\mathrm{H}_{2} \mathrm{O}$ to 35 kilobars: a better model for micas in the interior of the Earth; $A m$. J. Sci. $273385-414$

Nicholls I A and Whitford D J 1983 Potassium-rich volcanic rocks of the Muriah Complex, Java, Indonesia: products of multiple magma sources? J. Volcanol. Geotherm. Res. 18 337-359

Olafsson M and Eggler D H 1983 Phase relations of amphibole, amphibole-carbonate, and phlogopitecarbonate peridotite: petrologic constraints on the asthenosphere; Earth Planet. Sci. Lett. 64 305-315

Ryabchikov I D and Green D H 1978 The role of carbon dioxide in the petrogenesis of highly potassic magmas. In Problems of petrology of the Earth's crust and upper mantle. (Inst. Geol. Geofiz. Nauka, Novosibirsk) $40349-64$

Scott B H 1979 Petrogenesis of kimberlites and associated potassic lamprophyres from central West Greenland. In Kimberlites, diatremes and diamonds: their geology, petrology, and geochemistry (eds) F R Boyd and H O A Meyer (American Geophysical Union, Washington, U.S.A.) pp. 190-205

Sheraton J W and Cundari 1980 Leucitites from Gaussberg, Antarctica; Contrib. Mineral. Petrol. 71 417-427

Stern C R and Wyllie P J 1975 Effect of iron absorption by noble metal capsules on phase boundaries in rock-melting experiments at $30 \mathrm{~kb} ;$ Am. Mineral. $60681-690$

Takahashi E 1986 Melting of a dry peridotite KLB-1 up to $14 \mathrm{GPa}$ : implications on the origin of peridotitic upper mantle; J. Geophys. Res. 91 9367-9382

Thompson R N 1977 Primary basalts and magma genesis III. Alban Hills, Roman comagmatic province, central Italy; Contrib. Mineral. Petrol. 60 91-108

Treiman A H and Essene E J 1983 Mantle eclogite and carbonate as sources of sodic carbonatites and alkalic magmas; Nature (London) 302 700-703

Tronnes R G, Takahashi E and Scarfe C M 1988 Stability of K-richterite and phlogopite to 14 GPa; EOS, Trans. Am. Geophys Union 69 1510-1511

Upton B G J and Emeleus C H 1987 Mid-Proterozoic alkaline magmatism in southern Greenland: the Gardar province. In Alkaline lgneous Rocks (eds) J G Fitton and B G J Upton (Geol. Soc. London Spec. Publ.) 30 449-471 
Wallace M E and Green D H 1988 An experimental determination of primary carbonatite magma composition; Nature (London) 335 343-346

Wendlandt R F 1984 An experimental and theoretical analysis of partial melting in the system $\mathrm{KAlSiO}_{4}-\mathrm{CaO}-\mathrm{MgO}-\mathrm{SiO}_{2}-\mathrm{CO}_{2}$ and applications to the genesis of potassic magmas, carbonatites and kimberlites. In Kimberlites I: Kimberlites and related rocks (ed) J Kornprobst (Amsterdam: Elsevier) pp. $359-369$

Wendlandt R F and Eggler D H 1980 The origins of potassic magmas: 2. Stability of phlogopite in natural spinel therzolite and in the system $\mathrm{KAlSiO}_{4}-\mathrm{MgO}-\mathrm{SiO}_{2}-\mathrm{H}_{2} \mathrm{O}-\mathrm{CO}_{2}$ at high pressures and high temperatures; $\mathrm{Am}$. J. Sci. 280 421-458

Wendlandt R F and Mysen B O 1980 Melting phase relations of natural peridotite $+\mathrm{CO}_{2}$ as a function of degree of partial melting at 15 and $30 \mathrm{~kb} ;$ Am. Mineral. $6637-44$

Wyllie P J 1978 Mantle fluid compositions buffered in peridotite- $\mathrm{CO}_{2}-\mathrm{H}_{2} \mathrm{O}$ by carbonates, amphibole, and phlogopite; J. Geol. 86 687-713

Wyllie P J 1980 The origin of kimberlite; J. Geophys. Res. 85 6902-6910

Wyllie P J 1987 Volcanic rocks: boundaries from experimental petrology; Fortschr. Mineral. 65 249-284

Wyllie P J, Donaldson C J, Irving A J, Kesson S E, Merrill R B, Presnall D C, Stolper E M, Usselman T M and Walker D 1981 Experimental petrology of basalts and their source rocks. In Basaltic volcanism on the terrestrial planets (New York: Basaltic Volcanism Study Project, Pergamon) pp. 492-630

Wyllie P J and Huang W L 1975 Peridotite, kimberlite, and carbonatite explained in the system $\mathrm{CaO}-\mathrm{MgO}-\mathrm{SiO}_{2}-\mathrm{CO}_{2}$; Geology 3 621-624

Wyllie P J and Huang W L 1976 High $\mathrm{CO}_{2}$ solubilities in mantle magmas; Geology 4 21-24 